\title{
COMPOSITION, SEASONAL OCCURRENCES AND HABITAT USE OF BIRD ASSEMBLAGES IN WET FORESTS ON THE CENTRAL PLATEAU OF TASMANIA
}

\author{
by Raymond N. Brereton and Robert J. Taylor
}

(with five tables and four text-figures)

\begin{abstract}
BRERETON, R.N. \& TAYlor, R.J., 2000 (31:xii): Composition, seasonal occurrences and habitat use of bird assemblages in wet forests on the Central Plateau of Tasmania. Pap. Proc. R. Soc. Tasm. 134: 35-43. ISSN 0080-4703. Nature Conservation Branch, Department of Primary Industries, Water and Environment, Hobart, Tasmania, Australia 7000 (RNM); and Forestry Tasmania, 79 Melville Street, Hobart, Tasmania, Australia 7000 (RJT).
\end{abstract}

\begin{abstract}
Bird communities in montane wet forest at three sites (altitudes 700, 750 and $880 \mathrm{~m}$ ) on the Central Plateau of Tasmania were surveyed over a 12-month period between December 1991 and November 1992. Monthly transect counts were carried out at each site. Snowfalls are common at all three sites during winter and snow can remain at the highest site for several weeks. Bird communities at the study sites showed significant differences in densities and seasonal patterns even though species composition was similar. These differences were influenced by the variation in habitats and the environments at the sites. Butlers Road, the lowest site with the mildest winters and greatest proportion of drier habitat, had the highest bird densities, while D'Arcys Bluff, at the highest altitude, had the lowest. The degree of seasonal changes of birds was similar to mainland montane wet forests, with over half the species moving either locally or to the mainland. However, there was variation in seasonal occurrences between the study sites, with proportionally more species moving from the highest site during the winter. Within the study sites, the wet forest habitats with a diverse shrub and/or fern understorey supported higher bird populations than did mixed forest and damp forest. Species richness is lower at these sites compared with equivalent montane forests on mainland southeastern Australia.
\end{abstract}

Key Words: bird communities, montane wet forest, Tasmania, bird density, species diversity.

\section{INTRODUCTION}

There have been a number of studies conducted in southeastern Australia describing the composition, seasonal changes and habitat use in bird communities in a range of forest types, including temperate rainforest (Thomas 1980), wet forests (Lamm \& Wilson 1966, Pattemore 1980, Smith 1984, Loyn 1985a, 1993, Robinson 1991); dry forests and woodlands (Pattemore 1980, Recher et al. 1983, Recher \& Holmes 1985, Dickinson et al. 1986, Cale 1994, Mac Nally 1995, 1996, Taylor \& Haseler 1995). However, there has been only one major study of the bird communities of wet forest in Tasmania that collected information over all seasons, that carried out by Pattemore (1980) in the Florentine Valley. Of the studies of birds in southeastern Australia, few have been undertaken on the bird communities in montane forests, where the winters are exceptionally harsh and snow can be continually present for weeks. Gall \& Longmore (1978) and Osborne \& Green (1992) reported on studies in the Snowy Mountains. However, these were centred on alpine and subalpine communities. Lamm \& Wilson (1966) carried out a survey of the bird communities in montane wet forest in the Brindabella Range in the Australian Capital Territory and Thomas (1987) and Ratkowsky \& Ratkowsky $(1976,1978)$ reported on bird communities in montane wet forest on Mount Wellington in Tasmania.

This paper documents bird communities at three sites in montane Eucalyptus delegatensis wet forest on the Central Plateau of Tasmania. The patterns of seasonal occurrences and use of habitats at the three sites are compared and discussed in relation to other studies in forests in similar environments. This study was undertaken as part of the pre-logging data collection for a project investigating the value for fauna of retained strips in production forests.

\section{STUDY AREAS}

Three areas on the Central Plateau of Tasmania were sampled. These were D'Arcys Bluff (AMG 442053291 , elevation $880 \mathrm{~m}$, northwestern aspect), Hornes Dam (AMG $447553196,750 \mathrm{~m}$, southerly aspect) and Butlers Road (AMG $447353164,700 \mathrm{~m}$, southerly aspect). Jurassic dolerite underlies all three areas and forms a variably dense surface cover of Quaternary talus. Temperatures at the nearby settlement of Butlers Gorge $(666 \mathrm{~m})$ range from February mean daily minima and maxima of $6.2^{\circ} \mathrm{C}$ and $18.7^{\circ} \mathrm{C}$ respectively, to July mean daily minima and maxima of $-0.4^{\circ} \mathrm{C}$ and $6.9^{\circ} \mathrm{C}$ respectively. Snowfalls are common in winter, and at D'Arcys Bluff snow can lie on the ground for several weeks. Annual precipitation at Butlers Gorge, including snow, averages c. $1684 \mathrm{~mm}$, with a winter maximum and summer minimum.

Small areas of cool temperate rainforest dominated by Nothofagus cunninghamii are present at Butlers Road. Rainforest also occurs at Hornes Dam with Leptospermum lanigerum as a co-dominant. Vegetation at all three study areas is dominated by tall, open sclerophyll forest with c. 150-200 year old Eucalyptus delegatensis. The sclerophyll forest can be broadly subdivided on the basis of the affinities of the understorey species. Mixed forest has an understorey dominated by rainforest species. Wet sclerophyll forest has an understorey dominated by mesophytic (soft-leafed shrubs) and damp sclerophyll forest has an understorey with a mixture of species characteristic of both wet and dry forests. Shrub and ground cover varies within sites depending on canopy cover, dryness and surface rock abundance. The ground in wetter spots is bare under denser tree canopies, while the tree-fern Dicksonia antarctica is common in wetter, more open areas. On drier sites the shrub layer consists of a mixture of species including Cyathodes parvifolia, Pultenaea juniperina, Telopea truncata, 
Phebalium squameum, regrowth $N$. cunninghamii and Tasmannia lanceolata. On the more rocky sites dominant species include Bedfordia salicina, Notelaea ligustrina, $P$. squameum, Acacia verniciflua and Pomaderris apetala.

A vegetation survey of the study areas (F. Duncan \& $M$. Brown, pers. comm.) utilised classification techniques (TWINSPAN, Hill 1979) on cover-abundance floristic data to identify communities. Twelve communities were identified. Two of these are rainforest communities. The remaining ten communities contained $E$. delegatensis as the dominant tree. The twelve communities were combined into four habitat types by grouping communities with a similar structure and floristic affinities (table 1).

\section{METHODS}

A line transect method was used to survey birds. Two transects were located at Butlers Road, four transects at Hornes Dam and three transects at D'Arcys Bluff. Length of individual transects varied between $0.337 \mathrm{~km}$ and $0.484 \mathrm{~km}$. The transects were split into sections of different lengths (piece-wise linear design - Burnham et al. 1980) to enable the sampling of different habitats in non-homogenous terrain. Transect length in each habitat is given in table 2.

Transects were surveyed (by RB) during a ten-day visit to the study area during the middle of each month from December 1991 to November 1992. Transects at Butlers Road were surveyed once per monthly visit, apart from June when they were surveyed twice. The Hornes Dam and D'Arcys Bluff sites were surveyed twice per month with the following exceptions: due to poor weather conditions at Hornes Dam in December and January, two of the four transects were only surveyed once; at D'Arcys Bluff in December, one of the three transects was only sampled once; none of the transects at D'Arcys Bluff could be surveyed in June as heavy snowfalls prevented access to the site. Transects were traversed during the morning, generally during the first four hours after sunrise. Surveys sometimes extended beyond this time, when poor weather led to a delayed start.

The transects were traversed at a steady walking pace. All birds seen were recorded regardless of distance from the line. Birds that were heard and not located and birds flying overhead were noted but not included in the count. For each bird detected, a sighting distance and angle (between the line of travel and the line of sight to the object) were recorded.

Observations of birds were assigned to one of four height classes based on the structure of the vegetation and were decided prior to the commencement of the study. The height classes used were: canopy, $20+\mathrm{m}$ (E. delegatensis crowns); mid layer, 5-20 m (tall shrubs, secondary trees); lower layer, 1-5 m (shrubs); and ground layer, 0-1 m (ground surface, fallen timber, low shrubs).

Species were assigned to classes based on the height class in which they were most frequently observed over all seasons. These are dwelling height classes as opposed to foraging classes, because they are not based on observations of foraging activity. However, for most species they equate to the height class in which most foraging is undertaken. The exceptions are species such as the robins and the fan-tailed cuckoo, which pounce on invertebrate prey on the ground from low perches, and the forest raven, which forages across a range of height classes. The substrate on which a bird was perched when first detected was also recorded.

TABLE 1

The four habitats, their affiliation with current Tasmanian wet eucalypt forest classification and their occurrence in the study areas

\begin{tabular}{lcccc}
\hline Habitat types* & $\begin{array}{c}\text { Mixed forest } \\
\text { (MF) }\end{array}$ & $\begin{array}{c}\text { Mixed/wet forest with } \\
\text { dense ground ferns }\end{array}$ & $\begin{array}{c}\text { Mixed/wet forest with } \\
\text { a shrubby understorey }\end{array}$ & $\begin{array}{c}\text { Damp forest with a shrubby } \\
\text { understorey on rocky ground }\end{array}$ \\
& (WFf) & (WFs) & (DF)
\end{tabular}

Description

Cool temperate
rainforest and mixed
forest communities
and is characterised
by a dense secondary
tree layer.

Intermediate between a mixed and wet forest with $N$. cunninghamii usually sparse or absent as a secondary tree. Dry sclerophyll shrubs and/or wet ferns are common.

An open to dosed tall shrub layer is present.

Mixture of dry and wet forest shrubs. Present on areas with a high cover of rocks. Shrub layer varied from open to closed, particularly at Hornes Dam. Lomatia tinctoria was present in this community at Butlers Road.

DEL 1011 and DEL $0111 \mathrm{mixed} / \mathrm{wet}$ forest communities
DEL 0010 and DEL001 1 wet forest communities
Kirkpatrick et al (1988) classification mixed forest communities $\begin{array}{ll}\text { DEL 1000, DEL } & \text { DEL } 0111 \mathrm{mixed} / \text { w } \\ 1001 \text { and DEL } 1100 & \text { forest community }\end{array}$ $\begin{array}{ll}\text { DEL 1000, DEL } & \text { DEL } 0111 \mathrm{mixed} / \text { wet } \\ 1001 \text { and DEL } 1100 & \text { forest community }\end{array}$ $\begin{array}{ll}\text { DEL 1000, DEL } & \text { DEL } 0111 \mathrm{mixed} / \text { wet } \\ 1001 \text { and DEL } 1100 & \text { forest community }\end{array}$

Occurrence Butlers Road Hornes Dam D'Arcys Bluff

$\begin{array}{cc}+ & + \\ + & + \\ + & \text { limited }\end{array}$

absent
absent
+

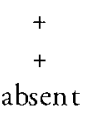

* The habitat types are listed in their probable order along an available moisture gradient from wettest to driest.
$\dagger+$ indicates that the habitat type occurs at that area. 
TABLE 2

Transect length in each habitat at the three study sites

\begin{tabular}{|c|c|c|c|c|c|}
\hline \multirow[t]{2}{*}{ Site } & \multicolumn{4}{|c|}{ Habitat } & \multirow[t]{2}{*}{ Total } \\
\hline & $\mathrm{MF}$ & WFf & WFs & $\mathrm{DF}$ & \\
\hline \multicolumn{6}{|c|}{ Length of transects $(\mathrm{km})$} \\
\hline $\mathrm{BR}$ & 0.486 & 0.472 & - & 0.209 & 1.167 \\
\hline HD & 1.174 & 0.652 & - & 0.426 & 2.252 \\
\hline DB & 0.920 & 0.039 & 0.828 & - & 1.787 \\
\hline \multicolumn{6}{|c|}{ Total length $(\mathrm{km})$ of transect sampled over the whole of the study } \\
\hline $\mathrm{BR}$ & 6.32 & 6.14 & - & 2.71 & 15.17 \\
\hline $\mathrm{HD}$ & 26.54 & 14.83 & - & 9.88 & 51.25 \\
\hline $\mathrm{DB}$ & 19.90 & 0.854 & 17.91 & - & 38.67 \\
\hline
\end{tabular}

Substrates included the ground (litter), rocks, fallen timber (trunks and branches $>100 \mathrm{~mm}$ ), stags (dead standing timber) and plant species. Incidental observations of foraging behaviour were also recorded.

Species were assigned a residency status based on their seasonal pattern of occurrence (from both sightings and calls) in the study area. Four categories were recognised: Resident - species was present all year

Summer visitor - species was only present in the summer months or present at other times in very low numbers relative to the size of the breeding population

Winter visitor - species was present only in the winter months or present at other times in very low numbers relative to the size of the non-breeding population

Itinerant - species was present in all seasons but not in all months. The species may or may not breed in the study area.

TRANSECT, a computer program which analyses line transect data (Laake et al. 1980, Burnham et al. 1980), was used to calculate total densities of birds. The estimates of density were carried out on truncated grouped data. The greatest observed distance formed the truncation point, except in some cases where extreme observations (outliers) were excluded from the analysis, as recommended by Laake et al. (1980). The significance of differences in density between sites and in different habitats was assessed by comparing the difference in the population means with the 95\% confidence interval for this difference.

Sorenson's index (Barbour et al. 1980) was used to compare the similarity of the species composition at the three sites.

\section{RESULTS}

The numbers of species observed (table 3) and the rate of detection (fig. 1) were greatest at Butlers Road and lowest at D'Arcys Bluff. Densities of birds were significantly higher at Butlers Road than at D'Arcys Bluff ( $p<0.05$, table 3), with densities at Hornes Dam not significantly different from the other two sites. Species composition (based on relative abundances within each site) was more similar at Butlers Road and Hornes Dam than at D'Arcys Bluff (Sorenson's indices: Butlers Road and Hornes Dam = 0.84; Hornes Dam and D'Arcys Bluff = 0.74; Butlers Road and D'Arcys Bluff $=0.67$ ).

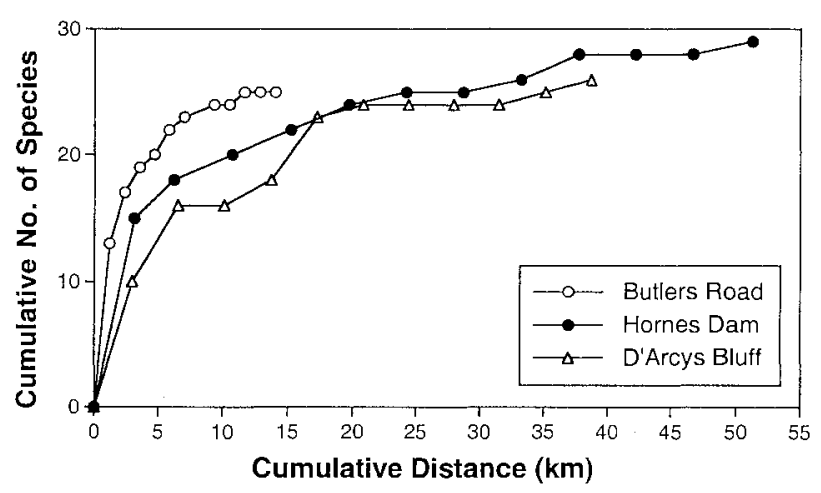

FIG. 1 - Number of species sighted as a function of the length of transect sampled.

\section{Seasonality}

Of the 32 species recorded during the study, 38\% were resident, $28 \%$ were summer visitors, $19 \%$ were winter visitors and $15 \%$ were considered to be itinerant to the area (table 3). Numbers of species tended to be lowest during winter and highest in late spring and early autumn (fig. 2).

The general seasonal pattern of sightings for resident species was low numbers in winter, an increase in early spring, followed by a decline in late spring-summer and an increase in sightings again in summer-autumn (e.g. Tasmanian scrubwren, fig. 3). However, two resident species, both honeyeaters, the strong-billed and the blackheaded honeyeater, were present in low numbers during summer, not recorded in some months post-breeding and showed a peak during winter (fig. 3).

The summer visitors were either species which breed in Tasmania and overwinter on the mainland (e.g. fan-tailed cuckoo, grey fantail (fig. 3), striated pardalote) or mainly local migrants which moved in from lower altitudes (e.g. flame robin, crescent honeyeater). The three mainland migrants, the black-faced cuckoo-shrike, grey fantail and silvereye, arrived in October and departed in April and May.

The winter visitors were all local migrants, although the brown thornbill is probably resident in low numbers at Butlers Road (fig. 3). The spotted pardalote was seen on only one occasion in spring at Butlers Road. The superb fairy-wren, grey butcherbird and grey currawong are casual winter visitors, only seen in low numbers and not at all sites. The superb fairy-wren was observed only at Butlers Road and not during transect counts.

The black currawong was the only itinerant species recorded breedirig at any of the sites. A nesting bird and juveniles were observed at D'Arcys Bluff and juveniles were also observed at Hornes Dam. The other four itinerant species were sighted on transects at some time during the breeding season and, thus, possibly also breed at the sites (fig. 3). All of the itinerant species are medium to largesized birds which range widely in search of suitable feeding and breeding areas. Thus, they may be resident in the area but only occasionally be present on transects. Sightings of the black currawong and the yellow wattlebird peaked in the post-breeding period. The increase in numbers in this period was in part due to the presence of post-breeding flocks. In particular, the black currawong was more often 
TABLE 3

Relative abundance of each species and total density of birds at three wet forest sites on the Central Plateau of Tasmania

\begin{tabular}{|c|c|c|c|c|}
\hline \multirow[b]{2}{*}{ Species } & & \multicolumn{3}{|c|}{ Abundance $e^{\ddagger}$} \\
\hline & & Butlers Road & Hornes Dam & D'Arcys Bluff \\
\hline \multicolumn{5}{|l|}{ Resident } \\
\hline Brush bronzewing & Phaps elegans & + & $0.04(1)$ & - \\
\hline${ }^{*}$ Green rosella & Platycercus caledonicus & $7.1(9)$ & $3.2(11)$ & $6.5(7)$ \\
\hline †Superb lyrebird & Menura novaehollandiae & + & $0.04(1)$ & $0.1(1)$ \\
\hline White's thrush & Zoothera dauma & $0.1(1)$ & $0.2(4)$ & $0.3(3)$ \\
\hline Pink robin & Petroica rodinogaster & $0.7(5)$ & $1.2(8)$ & $3.4(10)$ \\
\hline Olive whistler & Pachycephala olivacea & $0.4(4)$ & $0.4(8)$ & $0.1(1)$ \\
\hline Grey shrike-thrush & Colluricincla harmonica & $2.2(11)$ & $2.2(12)$ & $0.4(5)$ \\
\hline *Tasmanian scrubwren & Sericornis frontalis & $15.8(12)$ & $18.9(12)$ & $19.4(11)$ \\
\hline *Scrubtit & Sericomis magnus & $2.9(9)$ & $4.9(12)$ & $3.8(12)$ \\
\hline *Tasmanian thornbill & Acanthiza ewingii & $18.2(12)$ & $17.1(12)$ & $31.5(11)$ \\
\hline${ }^{*}$ Strong-billed honeyeater & Melithreptus validirostris & $23.4(11)$ & $16.9(11)$ & $7.6(6)$ \\
\hline *Black-headed honeyeater & Melithreptus affinis & $10.6(10)$ & $10.3(11)$ & $2.2(4)$ \\
\hline \multicolumn{5}{|l|}{ Summer visitor } \\
\hline Fan-tailed cuckoo & Cuculus pyrrhophanus & + & $0.04(1)$ & + \\
\hline Shining bronze-cuckoo & Chrysococcyx lucidus & $0.2(1)$ & + & $0.6(5)$ \\
\hline Black-faced cuckoo-shrike & Coracina novachollandiae & $0.3(2)$ & $0.4(5)$ & $1.0(3)$ \\
\hline Flame robin & Petroica phoenicea & $0.5(3)$ & $0.2(3)$ & $0.2(2)$ \\
\hline Grey fantail & Rhipidura fuliginosa & $2.7(6)$ & $1.9(7)$ & $1.0(6)$ \\
\hline Crescent honeyeater & Phylidonyris pyrrhoptera & $5.0(6)$ & $5.0(7)$ & $3.5(7)$ \\
\hline Eastern spinebill & Acanthorbyncus tenuirostris & + & $0.1(2)$ & $0.6(5)$ \\
\hline Striated pardalote & Pardalotus striatus & $0.7(4)$ & $1.0(5)$ & $3.0(6)$ \\
\hline Silvereye & Zosterops lateralis & $2.5(6)$ & $4.0(5)$ & $3.1(7)$ \\
\hline \multicolumn{5}{|l|}{ Winter visitor } \\
\hline Superb fairy-wren & Malurus cyaneus & + & - & - \\
\hline Brown thornbill & Acanthiza pusila & $2.6(9)$ & $0.6(4)$ & $1.1(4)$ \\
\hline *Yellow-throated honeyeater & Lichenostornus flavicollis & $0.7(6)$ & $0.4(4)$ & $0.6(3)$ \\
\hline Spotted pardalote & Pardalotus punctatus & $0.5(2)$ & $0.04(1)$ & $0.3(1)$ \\
\hline Grey butcherbird & Cracticus torquatus & $0.1(1)$ & - & - \\
\hline Grey currawong & Strepera versicolor & - & $0.1(1)$ & - \\
\hline \multicolumn{5}{|l|}{ Itinerant } \\
\hline Yellow-tailed black-cockatoo & Calyptorhynchus funerus & + & $0.1(1)$ & $0.5(1)$ \\
\hline Golden whistler & Pachycephala pectoralis & $0.5(4)$ & $0.04(1)$ & $0.2(1)$ \\
\hline *Yellow wattlebird & Anthochaera paradoxa & $1.5(5)$ & $1.9(8)$ & $0.8(4)$ \\
\hline *Black currawong & Strepera fuliginosa & $0.6(4)$ & $8.5(10)$ & $8.2(7)$ \\
\hline Forest raven & Corvus tasmanicus & $0.5(2)$ & $0.3(5)$ & + \\
\hline Density of birds (no./ha) & & $17.1 \pm 3.0$ & $11.5 \pm 1.6$ & $9.3 \pm 2.5$ \\
\hline No. of individuals & & 1038 & 2463 & 1140 \\
\hline No. of species on transects $\$$ & & 29 & 30 & 28 \\
\hline No. of species at site & & 32 & 30 & 30 \\
\hline
\end{tabular}

* Species endemic to Tasmania.

† Species introduced from mainland Australia.

* Percentage of total number of birds at each site. Number of months

a species was observed on the transects is shown in brackets.

observed in flocks outside of the breeding season. Flocks of $30-40$ birds were not uncommon and one flock of 400 birds was observed passing through D'Arcys Bluff in winter.

The pattern of seasonal changes in densities of birds differed between the sites (fig. 4). At D'Arcys Bluff densities were greatest during the autumn months, whereas at Hornes Dam highest densities were recorded during summer. Bird densities at Butlers Road were more uniform over the year, apart from two months of the year when densities were markedly different, being high in February and low in October.
+ Species present at site but not recorded on transect.

- Species not recorded at site.

${ }^{\$}$ Includes birds seen and heard.

\section{Use of Height Classes by Species}

The percentage of species in each height class use group was: canopy 37\%, mid layer 30\%, lower layer $20 \%$ and ground $13 \%$ (table 4). Birds which were recorded mostly in the lower layer, apart from the yellow-tailed black-cockatoo, also used the ground layer and the mid layer with little or no use of the canopy. Of the species classified as mid layer species, the brown thornbill, grey fantail and silvereye also had a high use of the lower layer and the grey shrike-thrush had a high use of the canopy. The crescent honeyeater had 


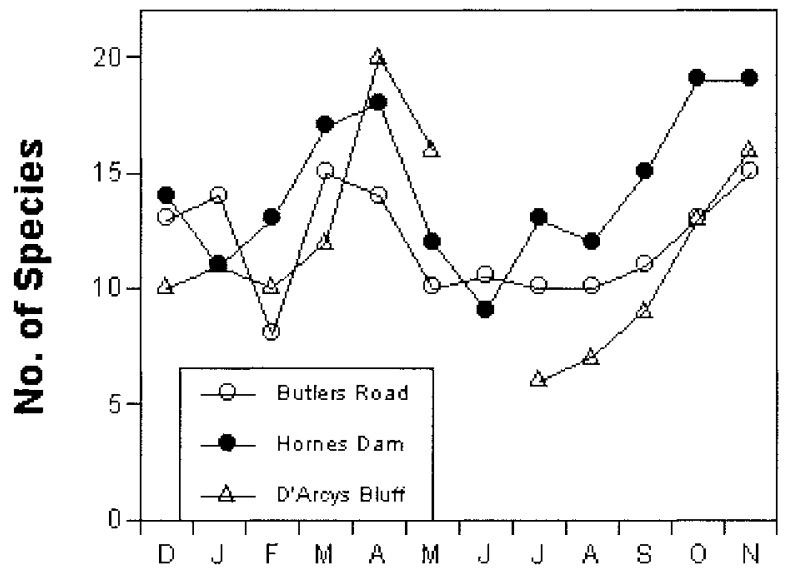

Month

FIG. 2 - Numbers of species sighted each month for the three study areas on the Central Plateau of Tasmania.
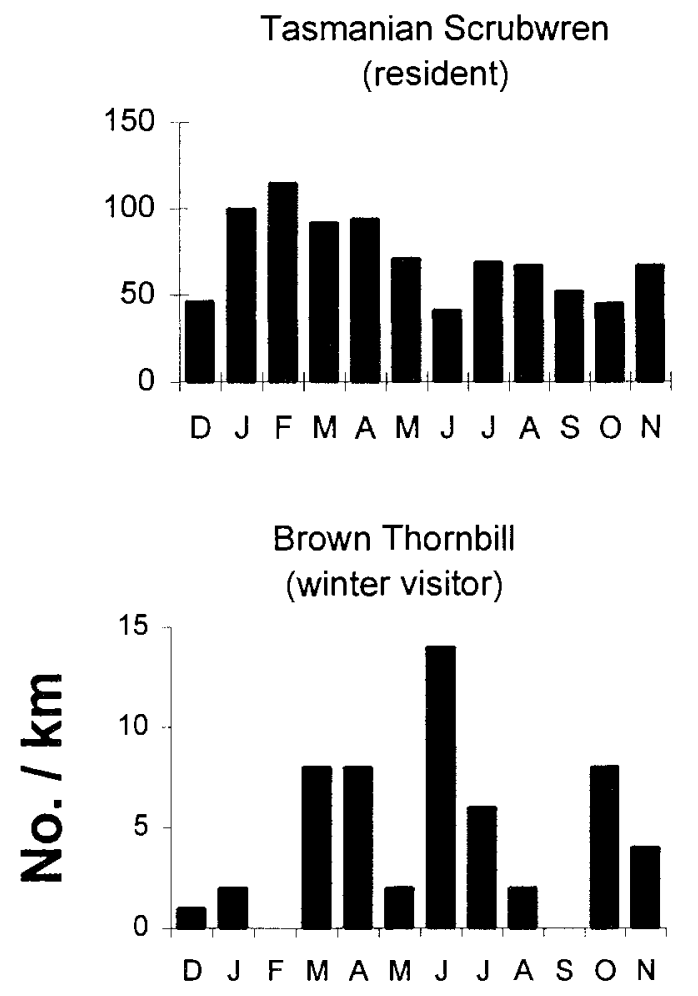

FIG. 3-Examples of species showing different seasonal patterns of occurrence.

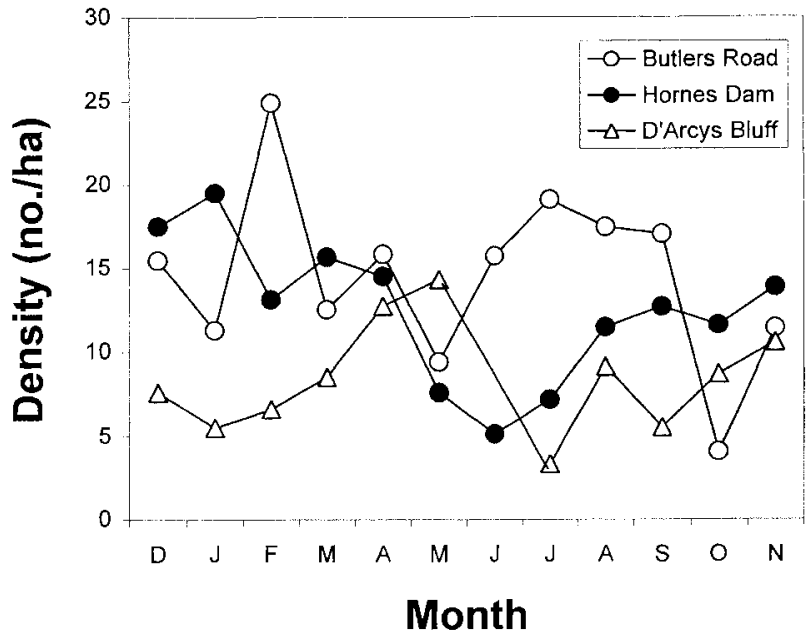

FIG. 4-Density of birds each month at the three study areas on the Central Plateau of Tasmania.

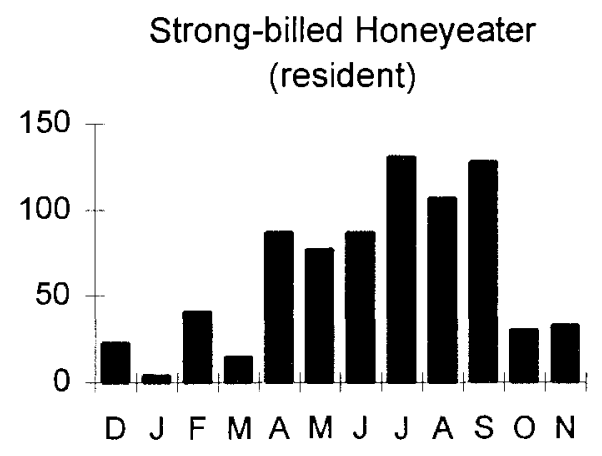

Grey Fantail

(summer visitor)
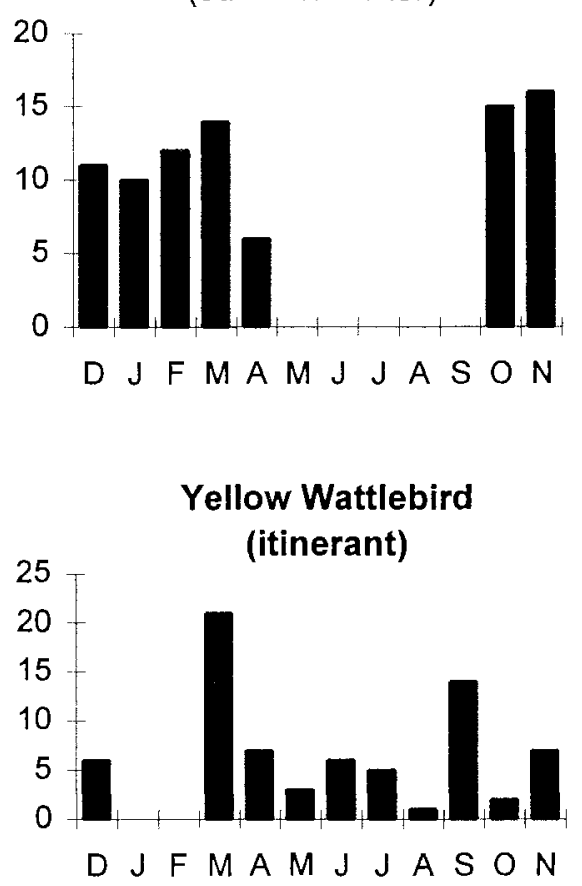

Month 
TABLE 4

Occurrence of species (\% of observations) in height classes across all study sites

\begin{tabular}{|c|c|c|c|c|c|c|}
\hline Species & Ground & Low & Mid & Canopy & $\mathrm{n}$ & Foraging strategy \\
\hline \multicolumn{7}{|l|}{ Canopy } \\
\hline Green rosella & 0 & 14 & 35 & 51 & 229 & $\begin{array}{l}\text { taking seed and probing under bark on trunks and } \\
\text { branches for invertebrates }\end{array}$ \\
\hline Spotted pardalote & 0 & 0 & 0 & 100 & 5 & gleaning invertebrates from foliage \\
\hline Striated pardalote & 0 & 0 & 12 & 88 & 60 & gleaning invertebrates from foliage \\
\hline Yellow wattlebird & 0 & 0 & 19 & 81 & 72 & $\begin{array}{l}\text { probing in and under bark on trunks and branches for } \\
\text { plant and insect exudates and invercebrates }\end{array}$ \\
\hline Yellow-throated honeyeater & 0 & 16 & 28 & 56 & 25 & $\begin{array}{l}\text { probing in and under bark on trunks and branches for } \\
\text { plant and insect exudates and invertebrates }\end{array}$ \\
\hline Strong-billed honeyeater & 0 & 1 & 27 & 72 & 762 & $\begin{array}{l}\text { probing in and under bark on trunks and branches for } \\
\text { plant and insect exudates and invertebrates }\end{array}$ \\
\hline Black-headed honeyeater & 0 & 3 & 20 & 77 & 381 & $\begin{array}{l}\text { probing in and under bark on trunks and branches for } \\
\text { plant and insect exudates and invertebrates }\end{array}$ \\
\hline Flame Robin & 17 & 24 & 17 & 42 & 12 & pouncing on invertebrates on the ground \\
\hline Golden whistler & 0 & 12 & 38 & 50 & 8 & snatching invertebrates from foliage and branches \\
\hline Black-faced cuckoo-shrike & 0 & 0 & 0 & 100 & 28 & snatching invertebrates from foliage and branches \\
\hline Forest raven & 0 & 0 & 19 & 81 & 16 & $\begin{array}{l}\text { taking invertebrates and fruits from all layers and } \\
\text { carrion from ground }\end{array}$ \\
\hline \multicolumn{7}{|l|}{ Mid layer } \\
\hline Fan-tailed cuckoo & 0 & 0 & 100 & 0 & 1 & pouncing on invertebrates on the ground \\
\hline Shining bronze-cuckoo & 0 & 22 & 56 & 22 & 9 & snatching invertebrates from foliage and branches \\
\hline Crescent honeyeater & 1 & 16 & 58 & 25 & 210 & $\begin{array}{l}\text { probing in and under bark on trunks and branches for } \\
\text { plant and insect exudates and invertebrates also taking } \\
\text { nectar }\end{array}$ \\
\hline Brown thornbill & 7 & 18 & 71 & 4 & 55 & gleaning invertebrates from foliage, branches and trunks \\
\hline Grey shrike-thrush & 4 & 10 & 52 & 35 & 83 & $\begin{array}{l}\text { probing in and under bark on trunks and branches for } \\
\text { invertebrates }\end{array}$ \\
\hline Grey fantail & 1 & 35 & 52 & 12 & 84 & hawking for insects \\
\hline Grey currawong & 0 & 0 & 100 & 0 & 2 & taking invertebrates and fruits from all layers \\
\hline Black currawong & 12 & 17 & 56 & 15 & 310 & taking invertebrates and fruits from all layers \\
\hline Silvereye & 6 & 19 & 69 & 6 & 171 & fruit, nectar and invertebrates from shrubs and trees \\
\hline \multicolumn{7}{|l|}{ Lower layer } \\
\hline Yellow-tailed black cockatoo & 0 & 44 & 22 & 33 & 9 & $\begin{array}{l}\text { taking seeds, probing for wood boring insect larvae and } \\
\text { other invertebrates }\end{array}$ \\
\hline Scrubtit & 37 & 51 & 7 & 5 & 217 & $\begin{array}{l}\text { probing for invertebrates on trunks, branches and the } \\
\text { ground }\end{array}$ \\
\hline Tasmanian thornbill & 9 & 48 & 40 & 2 & 983 & gleaning invertebrates from foliage and branches \\
\hline Eastern spinebill & 11 & 67 & 22 & 0 & 9 & taking nectar form the flowers of shrubs \\
\hline Pink robin & 20 & 53 & 25 & 2 & 81 & pouncing on invertebrates on the ground \\
\hline Olive whistler & 13 & 63 & 25 & 0 & 16 & snatching invertebrates from foliage and branches \\
\hline \multicolumn{7}{|l|}{ Ground layer } \\
\hline Brush bronzewing & 100 & 0 & 0 & 0 & 1 & taking seeds from the ground \\
\hline Superb lyrebird & 100 & 0 & 0 & 0 & 2 & probing in litter for invertebrates \\
\hline Tasmanian scrubwren & 82 & 17 & 0 & 0 & 856 & gleaning invertebrates from the ground \\
\hline Bassian thrush & 90 & 0 & 10 & 0 & 10 & probing in litter for invertebrates \\
\hline
\end{tabular}

TABLE 5

Density of birds* in each habitat at the three study sites

\begin{tabular}{lcccc}
\hline Sice & \multicolumn{4}{c}{ Habitat } \\
\cline { 2 - 5 } & MF & WFf & WFs & DF \\
\hline BR & $12.3 \pm 1.0$ & $20.9 \pm 1.3$ & - & $20.2 \pm 1.8$ \\
HD & $10.1 \pm 0.4$ & $16.8 \pm 0.8$ & - & $10.7 \pm 0.7$ \\
DB & $4.3 \pm 0.3$ & $14.1 \pm 1.0$ & $14.6 \pm 0.8$ & - \\
\hline
\end{tabular}

* No./ha \pm standard error. 
a high use of both the lower layer and the canopy. The black currawong was observed in all height classes. Species which occurred predominantly in the canopy, apart from the black-faced cuckoo-shrike, were also commonly observed in the mid layer with the green rosella and yellow-throated honeyeater also making use of the lower layer.

\section{Habitat Use}

At all sites, the densities of birds in wet forest with ferns (WFf) were either greater than other habitats or equivalent to one of the other habitats (table 5). Densities of birds were also lowest at all three sites in the same habitat, the wettest habitat mixed forest (MF), although at Hornes Dam densities were not significantly different from those in damp forest (DF). For each of the habitats there was a decline in density with altitude (i.e. Butlers Road > Hornes Dam > Darcys Bluff).

\section{DISCUSSION}

\section{Species Richness}

The number of species recorded during the study (32) is similar to that recorded in the three other studies of wet forest bird communities in Tasmania (Ratkowsky \& Ratkowsky 1976 - 30 species in $E$. delegatensis forest at 600-800m; Pattemore 1980 - 32 species in E. regnans mixed forest at $400-500 \mathrm{~m}$; and Thomas 1986 - 36 species in E. obliqua mixed forest at $600 \mathrm{~m}$ ). In a study of bird assemblages in montane dry forest, Taylor \& Haselar (1995) recorded 39 species of birds. This is consistent with other studies in Tasmania, which have shown that dry forests contain a greater number of bird species (Dickinson $e t$ al. 1986 - 49 species; Taylor et al. 1997 - 57 species) than wet forests. This contrasts with studies on the mainland, which have shown that wet eucalypt forests host more abundant and diverse bird communities than dry eucalypt forests (Loyn 1985b, 1993, Recher et al. 1985, 1991a, b).

Studies in montane wet forest on mainland southeastern Australia have recorded greater numbers of species than was recorded in this study (46 species - Robinson 1991; 65 species - Loyn 1985a; 63 species - Lamm \& Wilson 1966; 61 species — Osborne \& Green 1992). Like most islands, Tasmania has fewer bird species than the adjoining mainland, and consequently the avifauna of its forests is less diverse than similar forest on the mainland (Ridpath $\&$ Moreau 1966, Thomas 1974).

\section{Seasonal Occurrences}

There was considerable seasonal variation in the bird communities at the study sites. Over half of the bird species in the study area move away, either locally or to the mainland, at sometime during the year, and the resident species also displayed seasonal fluctuations in numbers. Similar seasonal changes have been documented in forests in southeastern Australia. Recher etal. (1983) observed that about half of the species at their study site in montane woodland in the Southern Tablelands of New South Wales were absent during the winter. In a study of birds in montane wet forest in the Brindabella Range in the Australian Capital Territory, $70 \%$ of species left the study site at some time during the year (Lamm \& Wilson 1966). Large-scale seasonal changes in species composition have also been recorded in other forest bird communities in southeastern Australia (Robinson 1991, Loyn 1985a, 1993, Mac Nally 1995). The same degree of seasonal variation in bird communities as found in this study has also been recorded in lowland dry sclerophyll forest ( $250 \mathrm{~m}$ a.s.l.) in southeastern Tasmania, where about half the species moved away from the study area at some time (Thomas 1986).

The pattern of changes in species richness over the year is similar to that observed by Recher et al. (1983) in montane forest in mainland southeastern Australia. This response to seasonal changes is primarily due to changes in the availability and abundance of insects and the flowering and fruiting of plants (Recher et al. 1983, 1991b, Recher \& Holmes 1985, Ford 1989).

Despite winter being the harshest season of the year, some species were only regularly observed at this time (e.g. the brown thornbill and yellow-throated honeyeater). These two species did occur in adjacent forests, and a small number of brown thornbills were recorded on occasions in summer at Butlers Road. It appears that during winter these species moved into the study sites as part of a pattern for species to move over larger areas in search of food.

The strong-billed honeyeater and black-headed honeyeater commonly formed mixed feeding flocks in the winter. Other species, such as the grey shrike-thrush, Tasmanian thornbill, crescent honeyeater and yellowthroated honeyeater occurred in these flocks on occasions. An influx of honeyeaters in the winter has been recorded in other montane forests in southeastern Australia (Robinson 1991, Loyn 1993, Recher \& Holmes 1985). These mixed feeding flocks foraged mainly under the loose bark shed by the upper trunk and branches of E. delegatensis. Bark is shed by eucalypts during late autumn and winter and provides a rich foraging substrate for birds (Recher et al. 1983, Turnbull \& Madden 1986). Manna and honeydew, both sugar-rich carbohydrate are abundant under loose and peeling bark, which also provides shelter for invertebrates over the winter months.

The number of species was at its highest in spring, when the summer migrants arrived back in the study area. Bird abundance also increased in spring. Shrubs such as Prostanthera lasianthos and Pittosporum bicolor were flowering at this time and provided a foraging resource for nectivores such as the eastern spinebill. This species moves in from lower altitudes to take advantage of this resource.

The summer decline in species diversity and abundance at the study area is most likely related to the behaviour of birds during the breeding season. In spring, when the summer migrants first arrive, detection of birds is facilitated by their involvement in territorial and mate selection behaviour, resulting in high counts. When birds have formed territories and are nesting it is likely that fewer individuals and fewer species will be detected along transects. After egg laying, birds are less conspicuous, and this probably also contributed to lower counts. However, there was variation between sites. Thus, in February Butlers Gorge had the lowest number of species and the greatest abundance of individuals. This variation in numbers of birds during late spring and summer was also recorded by Recher et al. (1983). 
The post-breeding increase in numbers of species, and to some degree bird abundance, was probably due to the presence of fledged birds appearing on the transects and was correlated with an increase in the number of flocks observed during the summer-autumn period. Passage migrants (e.g. black-faced cuckoo-shrike) and birds dispersing from other habitats (e.g. brown thornbill, yellowthroated honeyeater) began to appear at the study sites at this time of the year.

D’Arcys Bluff was characterised by greater environmental extremes, with colder winters and heavier and more frequent snowfalls than the two other sites. The seasonal movement of birds in areas with regular winter snowfalls has been related to the reduced availability of food caused by cold weather and shortened day length and the physiological demands of cold weather (Osborne \& Green 1992). Proportionally more species left D'Arcys Bluff during winter and moved back into the site during the breeding season compared to the other two sites. The difference between the minimum and maximum numbers of species per month seen on transects was 14 at D'Arcys Bluff compared with ten at Hornes Dam and seven at Butlers Road. This contrasted with variation in densities with the difference between the highest and lowest monthly density being 20.8/ha at Butlers Road, 14.4 at Hornes Dam and 10.9 at D'Arcys Bluff. Thus, although densities were lower at D'Arcys Bluff they were less variable than at the lower altitude sites. This may be due to smaller numbers of summer migrants moving in to this highest altitude site but greater numbers of species leaving the site to avoid the harsher winter conditions.

\section{Use of Height Classes}

The use of height classes by species at the site is similar to that found for the same species in montane forests on the mainland (Recher \& Holmes 1985) with two exceptions, the brown thornbill and the grey shrike-thrush. In forests on the mainland, the brown thornbill is found mostly in shrubs in the lower layer, where it mostly forages for invertebrates in the foliage (Recher et al. 1985, Loyn 1985). On the Central Plateau, the Tasmanian thornbill occupies this niche, being a wet forest species which gleans invertebrates from the foliage of shrubs and understorey trees. In contrast, the brown thornbill is mostly found in the midlayer, where it was often observed gleaning for invertebrates on the trunks of trees. The brown thornbill is predominately a winter visitor from surrounding drier forests and may be exploiting a substrate (the trunks of trees) in a height class which is little used at that time of the year. The brown thornbill was present in small numbers at Butlers Road through the summer; this site had a greater area of drier forest.

The grey shrike-thrush predominantly inhabits the ground and shrub layers on the mainland, where it takes invertebrates mainly from the ground and, to a lesser extent, from branches and loose bark (Recher et al. 1985). On the Central Plateau, this species was more often observed in upper layers, where it foraged on bark on the trunks and branches of trees. The extensive use of bark substrates by the brown thornbill and grey shrike-thrush has also been recorded by Cale (1994) in dry forests in northeastern Tasmania and by Keast (1968), who suggested it was due to the absence of the specialist bark foragers, the treecreepers (Climacteridae) and varied sittella Daphoenositta chrysoptera, from Tasmania.

There was a greater proportion of species classified as canopy species $(37 \%)$ and a lower proportion classified as ground species (13\%) compared with the study of Recher \& Holmes (1985) for montane forest in southeastern Australia (12\% and $32 \%$ respectively). These differences are probably related to the differences in forest structure, with Recher \& Holmes (1985) undertaking their study in regrowth with a much reduced canopy height $(17-22 \mathrm{~m})$ compared with our sites $(50-70 \mathrm{~m})$.

\section{CONCLUSION}

This study supports the findings of Mac Nally $(1995,1996)$ on the variability of bird communities. Thus it appears that bird assemblages of Tasmania, a large island, are as changeable as are continental bird communities. However, despite this changeability, broad-scale differences in the bird communities at these three study sites on the Central Plateau appeared to be related to local environmental changes over a relatively short altitudinal gradient.

\section{ACKNOWLEDGEMENTS}

Staff from Forestry Tasmania's Tarraleah Office provided much appreciated logistical support. Andrew Walsh and Darren Wilson assisted with data analysis. The study was funded by the Tasmanian Forest Ecology Research Fund.

\section{REFERENCES}

Barbour, M.G., Burk, J.H. \& Pitts, W.D., 1980: TERRESTRIAL PLANT ECOLOGY. Benjamin/ Cummings Publishing, Menlo Park.

Burnham, K.P., ANDERSON, D.R. \& LAAKE, J.L., 1980: Estimation of density from line transect sampling of biological populations. Wildl. Mono.72.

CALE, P., 1994: Temporal changes in the foraging behaviour of insectivorous birds in a sclerophyll forest in Tasmania. Ети 94: 116-126.

Dickinson, K.J.M, Wall, L.E. \& Wilson, R.I., 1986: Birds in a partly clearfelled dry eucalypt forest on dolerite in southeastern Tasmania. Pap. Proc. R. Soc. Tasm. 120: 39- 49.

FORD, H.A., 1989: ECOLOGY OF BIRDS: AN AUSTRALIAN PERSPECTIVE. Surrey Beatty and Sons Pty Ltd, Sydney.

Gall, B.C. \& Longmore, N.W., 1978: Avifauna of the Thredbo Valley, Kosciusko National Park. Emu 78: 189-196.

HILL, M.O., 1979: TWINSPAN: A FORTRAN PROGRAM FOR ARRANGING MULTIVARIATE DATA IN AN ORDERED TWO-WAY TABLE BY CLASSIFICATION OF THE INDIVIDUALS AND ATTRIBUTES. Cornell University, Ithaca, N.Y.

KEAST, A., 1968: Competicive interactions and the evolution of ecological niches as illustrated by the Australian honeyeater genus Melithreptus (Meliphagidae). Evolution 22: 762-784.

Kirkpatrick, J.B., Peacock, R.J. Cullen, P.J. \& Neyland, M.G., 1988: THE WET EUCALYPT FORESTS OF TASMANIA. Tasmanian Conservation Trust, Hobart.

LAAKE, J.I., BURNHAM, K.E. \& ANDERSON, D.R., 1980: USER'S MANUAL FOR PROGRAM TRANSECT. Share Program 
Library Agency, Program No. 360D-17.5.003. Triangle Universities Computation Centre, Research Triangle Park, N.C.

LAmM, D.W. \& WiLson, S.J., 1966: Seasonal fluctuations of birds in the Brindibella Range, Australian Capital Territory. Emu 65: 183-207.

LoYN, R.H., 1985a: Bird populations in succcessional forests of mountain ash Eucalyptus regnans in central Victoria. Emu 84: 213-230.

LOYN, R.H., 1985b: Ecology, distribution and density of birds in Victorian forests. In Keast, A., Recher, H.F., Ford, H.\& Saunders, D. (Eds): BIRDS OF EUCALYPT FORESTS AND WOODLANDS: ECOLOGY, CONSERVATION AND MANAGEMENT. Royal Australasian Ornithologists Union and Surrey Beatty and Sons: 33-46.

LOYN, R.H., 1993: EFFECTS OF PREVIOUS LOGGING ON BIRD POPULATIONS IN EAST GIPPSLAND: VSP RETROSPECTIVE STUDY. VSP Tech. Rep. 18. Department of Conservation and Natural Resources, Victoria.

MaC Naliy, R.C., 1995: On large-scale dynamics and community structure in forest birds: lessons from some eucalypt forests of southeastern Australia. Phil. Trans. R. Soc. Lond. 350: 369-379.

MAC NALLY, R.C., 1996: A winter's tale: Among-year variation in bird community structure in a southeastern Australian forest. Aust. J. Ecol. 22: 280-291.

Osborne, W.S. \& Green, K., 1992: Seasonal changes in composition, abundance and foraging behaviour of birds in the Snowy Mountains. Emu 92: 93-105.

Pattemore, V., 1980: Effects of the Pulpwood Industry on Wildlife in Tasmania. 3. Succession in bird communities and their habitats. Wildl. Div. Tech. Rep. 80/1. National Parks and Wildlife Service, Tasmania.

Ratkowsky, A.V. \& Ratkowsky, D.A., 1976: The birds of the Mt. Wellington Range, Tasmania. Emu 77: 19-22.

Ra'tKowsky, A.V. \& Ratkowsky, D.A., 1978: A survey of the birds of the Mt. Wellington Range, Tasmania, during the non-breeding months. Emu 78: 223-226

Recher, H.F. \& Holmes, R.T., 1985: Foraging ecology and seasonal patterns of abundance in a forest avifauna. In Keast, A., Recher, H.F., Ford, H.\& Saunders, D. (Eds) BIRDS OF EUCALYPT FORESTS AND WOODLANDS: ECOLOGY, CONSERVATIONAND MANAGEMENT. Royal Australasian Ornithologists Union and Surrey Beatty and Sons: 79-96.

Recher, H.F., Gowing, G., Kavanagh, R., Shields, J. \& RohanJONES, W., 1983: Birds, resources and time in a tablelands forest. Proc. Ecol. Soc. Aust. 12: 101-123.
Recher, H.F., Holmes, R.T., Schulz, M., Shields, J. \& KavanaGH, R., 1985: Foraging patterns of breeding birds in eucalypt forest and woodland of southeastern Australia. Aust. J. Ecol. 10: 399-419.

Recher, H.F., Kavanagh, R.P., Shields, J.M. \& Lind, P., 1991a: Ecological associations of habitats and bird species during the breeding season in southeastern New South Wales. Aust. J. Ecol. 16: 337-352.

ReCHer, H.F., MAJER, J.D. \& Ford, H.A., $1991 \mathrm{~b}$ : Temporal and spatial variation in the abundance of eucalypt canopy invertebrates: the response of forest birds. PROCEEDINGS OF THE 2OTH INTERNATIONAL ORNITHOLOGICAL CONGRESS. New Zealand Ornithological Congress Trust Board, Christchurch: $1568-1575$.

Ridpath, M.G. \& MoReau , R.E., 1966: The birds of Tasmania: ecology and evolution. Ibis 108: 348-393.

RoBInson, D., 1991: Changes in bird abundance between summer and autumn in East Gippsland montane forests. Vic. Nat. 108: 28-33.

SMITH, P., 1984: The forest avifauna near Bega, New South Wales 1. Differences between forest types. Emu 84: 200 210.

TAYlor, R.J. \& Haseler, M.E., 1995: Effects of partial logging systems of bird populations in Tasmania. For. Ecol. Manage. 72: 131-149.

TAylor, R., Duckworth, P., Johns, T., \& Warren, B., 1997: Succession in bird assemblages over a seven-year period in regrowth dry sclerophyll forest in south-east Tasmania. Ети 97: 220-230.

Thomas, D.G., 1974: Some problems associated with the avifauna. In Williams, W.D. (Ed.): BIOGEOGRAPHY AND ECOLOGY IN TASMANIA. W. Junk, The Hague, Netherlands: 339-365.

THOMAS, D., 1979: TASMANIAN BIRD ATLAS. FAUNA OF TASMANIA HANDBOOK NO. 2. University of Tasmania, Hobart.

Thomas, D.G., 1980: The bird community of Tasmanian temperate rainforest. Ibis 122: 298-306.

Thomas, D.G., 1986: The birds of Mt Wellington - Comparison of two 19 ha plots of dry and wet sclerophyll. Tasm. Bird Rep. 15: 11-16.

Thomas, D.G., 1987: The effect of hard weather on bird abundance. Tasm. Bird Rep. 16: 17-20.

Turnbuli, C.R.A \& Madden, J., 1986: Litter accession, accumulation and decomposition in cool temperate forests of southern Tasmania. Aust. For. Res. 16: 145-153.

(accepted 17 May 2000) 